\title{
PATH ANALYSIS ON THE EFFECT OF AMBIENT SMOKE AND OTHER RISK FACTORS ON PNEUMONIA AMONG CHILDREN UNDER FIVE IN KARANGANYAR, CENTRAL JAVA
}

\author{
Atika Nikmah'), Setyo Sri Rahardjo²), Isna Qadrijati²) \\ 1)Masters Program in Public Health, Universitas Sebelas Maret \\ 2) Faculty of Medicine, Universitas Sebelas Maret
}

\begin{abstract}
Background: Pneumonia remains the leading killer of children beyond the neonatal period, but substantial progress was made in the past decade in reducing pneumonia-related mortality. According to UNICEF, global deaths from pneumonia among children decreased 35\% from 1.8 million in 2000 to 1.1 million in 2012. This study aimed to examine the effect of ambient smoke and other risk factors on pneumonia among children under fivein Karanganyar, Central Java.

Subjects and Method: This was a case control study conducted in Karanganyar District, Central Java, from October to November 2017. Study subjects were selected by fixed disease sampling consisting of 68 children under five years old with pneumonia and 136 without pneumonia. The dependent variable was pneumonia. The independent variables were nutritional status, exclusive breastfeeding, maternal stress, type of labour, maternal education, maternal job status, family income, quality of house, quality of environment, and indoor smoke exposure. The data was collected by questionnaire and analyzed by path analysis.

Results: The risk of pneumonia increased with ambient smoke exposure $(b=$ 2.63; 95\% CI $=1.70$ to $3.55 ; \mathrm{p}<0.001)$. The risk of pneumonia decreased with good house environment $(\mathrm{b}=-0.93 ; 95 \% \mathrm{CI}=-1.72$ to $-0.14 ; \mathrm{p}=0.020)$, healthy behavior $(\mathrm{b}=-1.41 ; 95 \% \mathrm{CI}=-2.22$ to $-0.60 ; \mathrm{p}=0.001)$, and good nutritional status ( $b=-1.83 ; 95 \% \mathrm{CI}=-2.72$ to $-0.93 ; \mathrm{p}<0.001)$. The risk of pneumonia was indirectly affected by quality of house, exclusive breastfeding, maternal stress, history of Cesarean section, number of children, maternal education, family income, and maternal employment.

Conclusion: The risk of pneumonia increases with ambient smoke exposure, but decreases with good house environment, healthy behavior, and good nutritional status.
\end{abstract}

Keyword: risk factor, ambient smoke, pneumonia, children under five

\section{Correspondence:}

Atika Nikmah. Masters Program in Public Health, Universitas Sebelas Maret, Jl. Ir. Sutami 36 A, Surakarta 57126, Central Java.

Email: atikanikmah123@gmail.com. 